\title{
CREDIT WHERE IT'S DUE
}

\section{By H.J. Leamy \\ MRS President}

At the Society's Council meeting in January it was my pleasure to present to the outgoing president, Clyde Northrup, a token of the MRS's appreciation for the hard and fruitful work he had done. On that occasion, Clyde remarked to me that $I$ would be astounded at the amount that could be accomplished if no concern were paid to the allocation of credit. This remark is typical of Clyde Northrup, whose diligent efforts on behalf of the MRS were never accompanied by demand for recognition. Indeed, so strenuous were his labors that I had initially thought to entitle this piece, "Clyde Northrup, R.I.P.!" I was, alas, overruled by the editor of the Bulletin, who feared that it might be mistaken for an obituary. In fact, Clyde is lost neither to the world nor the MRS. He now assumes the office of Immediate Past President, which while somewhat less arduous than that of president is no less important.

Clyde Northrup leaves as the chief executive of the MRS a model for myself and other officers to follow. He presided over unprecedented growth of the Society, and formulated an organizational structure to direct and enhance that growth. He brought to his duties a sense of discipline; a business-like approach toward a professional society of individuals with disparate backgrounds. He labored to put in place a structure that would serve the Society's organizational needs not just during his tenure but in the future as well. Specifically, under Clyde's leadership the:

- By-laws were revised to streamline the duties of the leadership and increase organizational effectiveness;

- Committee structure was reformed, committees' activities clearly defined and given boundaries by the By-laws;

- MRS Bulletin was reborn.

- First MRS meeting to be held in Europe (Berlin - 82) was organized and conducted with Clyde's active encouragement; and

- New letters journal, Materials Letters, was published in association with the MRS.

Thus much of what Clyde sought for the MRS has already borne fruit, but much will not be realized until future years. For example, the organizational framework he conceived and directed can underlie a much larger organization than the present MRS, with an even greater presence internationally. Yet as it grows the Society is well served by the same apparatus.

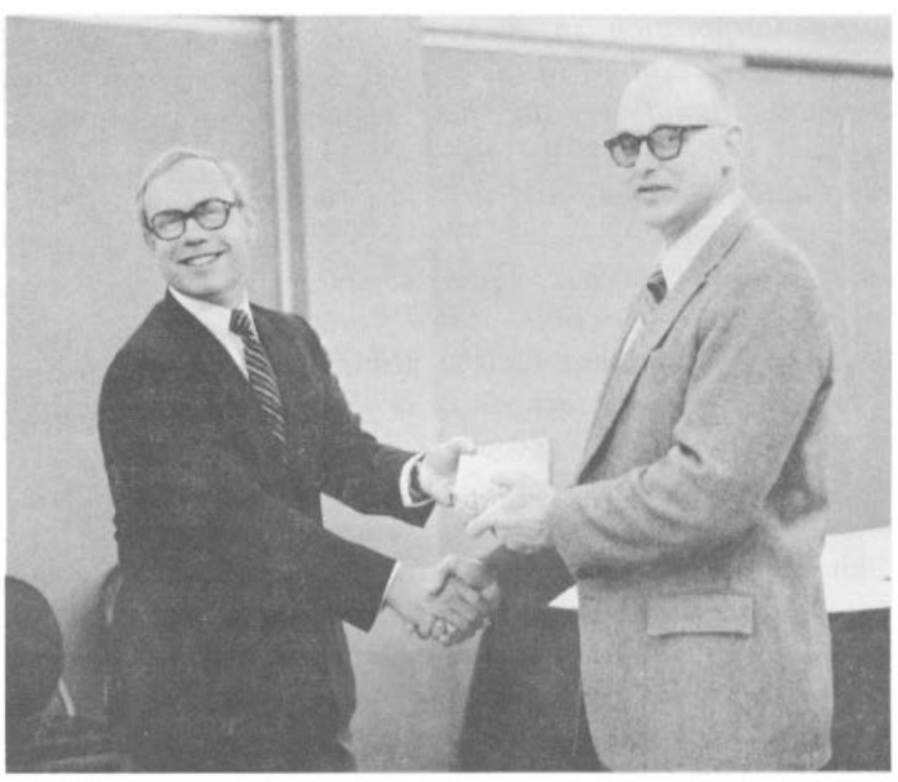

CLYDE NORTHRUP (right) congratulated by 1983 President H.J. Leamy

Clyde's farsightedness is evident in another of his current interests, which is explained elsewhere in this number of the Bulletin. This is the development of an international system for computerized materials data bases. The MRS is fortunate to have had Clyde's leadership during our recent period of dynamic growth. We look forward to his continuing participation in the Society's affairs in the years to come. 